\title{
Interpretation of Historical Values of Sunan Kudus: Religious Moderation in Indonesian Islamic Boarding Schools
}

\author{
Ihsan $^{1^{*}}$, Irwan Abdullah ${ }^{2}$ \\ ${ }^{1}$ Institut Agama Islam Negeri (IAIN) Kudus, Indonesia \\ ${ }^{2}$ Universitas Gadjah Mada (UGM) Yogyakarta, Indonesia \\ *Corresponding author, Email: ihsan@iainkudus.ac.id
}

\begin{abstract}
This study aims to understand the typology of religious moderation based on historical values of Sunan Kudus at Islamic Boarding Schools (Madrasah - Pesantren) in the Eastern region of North Coast Road (East Pantura), Indonesia. This study used a qualitative approach by collecting interview and observation data at five Islamic Boarding Schools in the East Pantura region, they are MA Al-Wathoniyah Semarang, MA Qudsiyyah Kudus, MA Al-Hidayah Kudus, MA Al-Anwar Sarang Rembang and MA al-Hidayat, Lasem Rembang. The results of this study indicated that the moderate Islamic style of Sunan Kudus appears in the Islamic Boarding Schools in Pantura area which is broadly depicted in their activities that encourage tolerance, build a thinking tradition based on Islamic scientific knowledge and strengthen national education with an Islamic perspective to avoid radical behaviors. This study has a contribution and urgency to the development of moderate Islamic Boarding Schools, as well as a generation and society that is tolerant, peaceful and of character. This research produces a moderate Islamic education model that rooted in the history of Islam in the archipelago which could serve as the basis for religious moderation in Islamic educational institutions.
\end{abstract}

\section{Keywords: Historical values, Walisongo, Religious Moderation, Islamic Boarding School.}

\section{INTRODUCTION}

Religious moderation has become one of the main issues in religious life in Indonesia. This is due to the policy of the Minister of Religious Affair of the Republic of Indonesia (2014-2019), who uses this theme as a strategy for moderating the religious life. In contrast to the deradicalization and counter-radicalism strategies, religious moderation puts forward positive steps by moderating religious views and understandings, especially for Muslims in Indonesia.

How was the typology of religious moderation in the Islamic Boarding Schools in Indonesia? This is the research question of this paper. Within this framework, this paper departs from the theoretical framework of religious moderation which has historically been carried out by the preachers of early Islam, especially in Java, known as Walisongo. The focus of this study is on the interpretation of historical values of Sunan Kudus, which contain the noble values of teachings, local wisdom and the Menara Kudus architectural building that shows the significance of peace and tolerance. This means that religious moderation is not only carried out by religious stakeholders today. However, it has long been done by the Wali in Java, especially Sunan Kudus in the $13^{\text {th }}$ to $16^{\text {th }}$ century AD. This is what makes Islam in Nusantara/Indonesia moderate, tolerant and rooted in the culture of society. 
Religious moderation is defined as the process of making moderate religious understanding characterized by the "middle way" understanding between various extreme points, both right and left-wing extremism. This moderation is also commonly referred to as wasathiyyah (middle way) which is the characteristic of Islam in Indonesia [1]. Among the Nahdlatul Ulama (NU), for example, the wasathiyyah principle is characterized by several attitudes such as balance (tawazun), tolerance (tasammuh) and moderate (tawassuth) itself. Balance means being impartial in judging. Being tolerant of something different. And moderate among various extremism. The extreme point in question is the conservative-radical paradigm (right-wing) on the one hand, and liberal (left-wing) on the other one.

The conservative-radical view is rooted in a closed understanding and interpretation of Islamic teachings. With their slogan "Back to Qur'An and Sunnah Way", this view rejects anything that is textually absent in these two sources of Islamic law. Users of this slogan are commonly referred to as "purification groups" which purify Islam from elements that are considered outside of Islam [2].

This conservative attitude is also found in their assessment towards non-Muslims. For purification groups, all religions outside of Islam are condemned as kafir. Of course, this is a dimension of the creed of Islam. But QS. alMaidah: 48 also emphasized that Allah SWT deliberately created humans in various types (including religious diversity), to test how wise mankind is in responding to differences. Islam also teaches various kinds of brotherhood, namely brotherhood among Muslims (ukhuwah Islamiyyah), brotherhood among fellow citizens (ukhuwah wathaniyyah), and brotherhood among humans (ukhuwah basyariyyah). This conservative-radical paradigm then gave birth to a "takfiri ideology" which ease these radical groups to label everyone different from them as kafir, including fellow Muslims with different views [4].

The radicalism virus in education has caused a certain percentage of our students to no longer respect the official foundational philosophical theory of Indonesia, Pancasila. For them, Pancasila is considered as the basis of a kafir state which is incompatible with Islam. Several survey findings have identified this trend. The Alvara Research Center survey in 2017 explained that $18.6 \%$ of our students agreed more with Islam as the basis of the state, rather than Pancasila $(81.3 \%)$. The same attitude was shared by $16.8 \%$ of our students and $15.5 \%$ of our professionals. What is meant by Islam as the basis of this state is the basis of an Islamic state in general, and the basis of the Islamic Khilafah state was developed by Hizbut Tahrir Indonesia (HTI), an Islamic organization that has been banned by the government.

Likewise, a national survey conducted by Saiful Mujani Research and Consulting (SMRC) in May 2017, found a certain percentage of students who agreed with and supported terrorism and radicalism carried out by the Islamic State of Iraq and Syria (ISIS) and Hizbut Tahrir Indonesia (HTI). The survey findings are as follow: there are $3.3 \%$ high school students, $2.4 \%$ middle school students, and $1.6 \%$ grade school students who agree and strongly agree with ISIS. It is a dangerous behavior considering ISIS is a terrorist organization. Therefore, these $3.3 \%$ of students agreed with terrorism. Likewise, there are $11.6 \%$ high school students, $7 \%$ middle school students and $11.1 \%$ grade school students who agree and strongly agree with HTI. This is considered a large number for the regeneration of this movement. The findings of this survey are certainly a warning for the future of religious moderation in the world of Islamic education and this nation as a whole.

At the same time, religious moderation also wants to spare Muslims from the left-wing extremism, namely the Islamic pattern that uses the paradigm of liberalism, secularism, and pluralism to approach Islam. Liberalism places individual freedom as the main measure in religion. This freedom mainly lies in the superiority of intelligence in interpreting the revelation from God. Whereas secularism develops the principle of separation of religion and state, one thing that is contrary to the scope of Islamic sharia, which not only regulates personal but also social life. Meanwhile pluralism develops the principle of equality of religions (wahdatul adyan), even though every religion has different theology and laws. Likewise, moderate Islam develops an appreciation for plurality (plurality facts) minus pluralism.

In this paper, the moderate Islamic style and the process of religious moderation explored in the MadrasahPesantren (MP) environment take interpretation and inspiration from the Islamic style of Sunan Kudus strategy. The purpose of this study is to understand the typology of religious moderation based on the historical values of Sunan Kudus at the Islamic Boarding Schools in East Pantura, Indonesia. This has 
contributed to moderate Islamic education and the cultivation of peace and tolerance for the nation's future generations.

\section{METHOD}

In accordance with the objectives and results to be achieved in the intended research, the qualitative approach was chosen with a naturalistic paradigm and philosophically refers to the post-positivism phenomenology. This study involved several Islamic Schools in the Pantura area, including; Madrasah Aliyah Al-Hidayat Lasem, MA Al-Anwar 2 Sarang, MA AlWathoniyyah Semarang, MA Al-Hidayah Kudus, and MA Qudsiyyah Kudus. The researchers explored the data in two stages, namely; data collection from human sources, and data collection from non-human sources. The method of data collection for the first type of source includes in-depth interviews with several informants including the Headmaster of the Islamic School and the Head of the Islamic Boarding School. Meanwhile, documentation is used for the second type of source. To ensure that the data obtained through documentation and interview can be accounted for, it is absolutely necessary to check the validity of the data (trustworthiness), through 1) credibility; 2) transferability; 3) dependability; and 4) confirmability.

\section{RESULT AND DISCUSSION}

\subsection{Typology of Religious Moderation Based on the values of Sunan Kudus Teachings}

One of the efforts of the government to maintain the integrity of the Republic of Indonesia is to promote understanding related to religious moderation. This moderation is one of the efforts to prevent the existence of intolerance, exclusivism, extremism and terrorism, because they will no doubt threaten the unity of the nation if allowed. The exclusive religious style has produced many intolerance and violence in the name of religion.

Moderation comes from the word moderate, which means taking the middle way, meaning it is neither right nor left-wing extremes [5]. This attitude is one of the characteristics of Islam. Many literatures defined the concept of moderate Islam, one of them is as-Salabi who argues that moderate (wasathiyah) has many meanings, namely between the two ends, being elected (khiyar), fair, best, special, and something that is between good and bad. [6]. In line with as-Salabi, Kamali gives the meaning of wasatiyah with tawassut (middle), 'itidal (perpendicular), tawazun (balanced), iqtishad (not excessive) [7].
Meanwhile, Qardlawi gives a broader meaning to wasatiyah such as justice, istiqamah (straight), being elected or the best, security, strength, and unity [8].

Apart from the many literal meaning of moderate, it can be elaborated into religious understanding. For example, according to Hilmy in the context of Indonesian Islam, the use of the concept of moderate Islam has five characteristics, namely [9];

1) ideology without violence in spreading Islam;

2) adopting a modern way of life with all its derivatives, both in the fields of science and technology, democracy, human rights, etc.;

3) think rationally;

4) a contextual approach in understanding Islam; and

5) the use of ijtihad model (intellectual work to make legal opinions if there is no explicit justification from the Qur'an and Hadith).

The concept of religious moderation offered by Islam is tawazzun (balance), i'tidal (straight and firm), tasammuh (tolerance), musawwah (egalitarian), shura (discussion), ishlah (reformation), aulawiyah (prioritizing the priority), tathawwur wa ibtikar (dynamic and innovative) [10].

The existence of a moderate attitude in religion cannot be separated from the source of the teaching. In the context of Indonesia and Java in general, the preachers of religion are the Walisongo and one of them is Sunan Kudus.

Sunan Kudus with the real name Ja'far Shodiq is one of the Walisongo who preach Islam in Kudus area. Many opinions are related to the lineage of Sunan Kudus, but from these differences there is a common thread that connects one lineage to another.

In the explanation of Sunan Kudus lineage, Said explained that Sunan Kudus' real name is Ja'far Shodiq, also called as Raden Hajji with the title of Sunan Ngudung in Jipang Panolan. He is the son of Raden Usman Haji Raja Pandita bin Ibrahim al-Samarqandi bin Maulana Muhammad Jumadi al-Kubra bin Zaen al-Husain bin Zain al-Kubra bin Ali Karamallah wajhah [11].

Hikayat Hasanuddin mentioned that the father and son were known as religious experts and persistent preachers of Islam. Sunan Kudus, whose real name was Amir before becoming known as Ja'far Sadiq, was the fifth imam (religious leader) of the Demak Mosque at the end of Sultan Trenggana era and at the beginning of Sultan Prawata era. 
Sunan Kudus moved from Demak and "founded" Kudus city after his disagreements with the Sultan of Demak in determining the starting date of Ramadhan [12].

It is not clear when exactly Jafar Shodiq arrived in Kudus. When Jafar Shodiq set foot in Kudus, the city was still called Tajug. The settlement existed before the arrival of Jafar Shodiq. At Tajug, Jafar Shodiq initially lived among congregations in small group. Some interpreted that the Ja'far Shodiq congregation was the retainer and followers he brought from Demak. They were soldiers who joined Ja'far Shodiq in fighting Majapahit. Another version stated that his followers were local residents, who worked with Jafar Shodiq to cultivate the fields. This can be interpreted that Jafar Shodiq originally lived off working on agricultural land [13].

In his preaching activities, Sunan Kudus has a method that is quite unique to the acculturation of Hindu civilization that has developed previously. This is proven by the prohibition against slaughtering cows which are considered sacred animals in Hinduism.

In addition, providing information about the beginning of Ramadan or the month of fasting was done using the method of hitting the drum repeatedly in the hope that the congregation could gather at the mosque. After the congregation has gathered, Sunan Kudus announced the exact day of fasting. This event is still being preserved and is known as Dhandang bedhug.

In the form of monumental artifacts of Sunan Kudus, there is a tower located beside the front left of the mosque. Abdul Jalil, one of the board members of the Masjid Menara and Makam Sunan Kudus Foundation, stated that the tower next to the mosque is clearly built like a temple or a Balinese temple tower. Some researchers associated the shape of the tower with the Jago temple, especially when viewed from the architecture and the similarity of the tumpal decoration. There are also those who compare Menara Kudus to the temple in Singosari. There is a place of ablution next to the yard. Interestingly, there is an ornament in the form of eight statue heads at the faucet area.

He also explained that the eight faucets contain the philosophy of Astasanghikanarga in Buddhism, namely knowledge, decisions, words, actions, livelihood, effort, meditation, and contemplation.
In principle, the teachings of Sunan Kudus, through practice and artifact heritage, are affirmed to create humane justice and prosperity within a divine frame.

Every citizen must be ensured that they can actualize themselves and achieve their goals in accordance with their potential. Achieving such conditions necessitates the enforcement of justice, equality, solidarity, and participation encapsulated in the framework of civilized values and noble social ethics.

\subsection{The Typology of Religious Moderation in Islamic Boarding Schools in Indonesia}

The religious moderation education in these five MPs was developed through several things. First, the establishment of a tolerant attitude through the strengthening of brotherhood (ukhuwah diniiyyah, wathoniyyah and basyariyyah) with an emphasis on the brotherhood of the same faith people, maintaining national brotherhood and developing human brotherhood. This is as practiced by the founders of Islamic Schools who always prioritize a tolerant attitude in their actions in society. For example, KH Muhammad Zaim, the educator in Islamic boarding school and Madrasah Aliyah Al-Hidayat Lasem, always teaches about tolerance to his students. He gave examples of behavior that reflected these values, such as being tolerant towards Chinese descendants, therefore, the students saw firsthand what the teachers were doing. He further said that because of the location of Al Hidayat Lasem Islamic boarding school, which is adjacent to the Chinese community, it is often for some Chinese descendants to come and see Gus Zaim to just chat to have serious discussions, this chat is not necessarily in a special place, but on the front porch of the house to be relaxed. Besides that, the students walking around the resident are able to see this view and treat it as a lesson for them about the meaning of ukhuwah basyariyah. Another thing is that every time a Chinese descendant dies, Gus Zaim always asks his wife to participate in takziyah or mourning the dead before the body is buried. This is an extraordinary thing and is a powerful way to instill a moderate attitude in the students by giving direct examples to the students. It is known by the term hidden curriculum but real in the learning process. Hidden curriculum connotation has two dimensions, namely dimension related to the teacher behavior, and dimension related to the implementation of the teacher's concept of what, who and how students are enforced to achieve learning objectives, but not how learning materials are taught. In essence, the hidden 
curriculum is a "bypass" to realize the goals of national education [14].

Second, the Islamic education curriculum with salaf (traditional) nuances which builds a thinking tradition based on Islamic scientific knowledge. This is done by enriching the Religious Literacy in order to foster an attitude of religious moderation for students in Islamic boarding schools. Students must be literate with religious sources. The religious source can be understood through the understanding of Kitab Turats which are often known as Kitab Kuning (lit. yellow books). In the context of the religious literacy practice, boarding schools have references based on the original literacy (salafiyah) as shown in the table 1 .

Table 1. The Original Literacy of Boarding Schools

\begin{tabular}{|l|l|}
\hline Schools & Salafi Books \\
\hline $\begin{array}{l}\text { MA Al Anwar, } \\
\text { Sarang }\end{array}$ & $\begin{array}{l}\text { Bulughul Maram, Safinatun Naja, } \\
\text { Tafsir Jalalain, Taqrib, kailani }\end{array}$ \\
\hline $\begin{array}{l}\text { MA Al } \\
\text { Lasem }\end{array}$ & $\begin{array}{l}\text { Fathul Qarib, Tasawuf, Mantiq, } \\
\text { Muhadatsah, Tafsir, Hadis, } \\
\text { Musthalah hadis, Tajwid }\end{array}$ \\
\hline $\begin{array}{l}\text { Qudsiyyah, } \\
\text { Kudus }\end{array}$ & $\begin{array}{l}\text { Tafsir Jalalin, Bulughul Marom, } \\
\text { Tuhfatul Murid, Takhrir, Sulamul } \\
\text { Munawaroh, Qifayatul Atqiyak, } \\
\text { Lubabul Ushul, Faroidus Sanniyyah } \\
\text { wa Durorul Bahiyyah, Durusul } \\
\text { Falaqiyah, Ibnu Aqil-Sarah alfiyah, } \\
\text { Uqudul Juman, Mustholah Hadith, } \\
\text { idlotun nasyi'in, Tasrihul Yasir }\end{array}$ \\
\hline $\begin{array}{l}\text { MA Al } \\
\text { Kudayah, }\end{array}$ & $\begin{array}{l}\text { Durusul Faroid, Alfiyah, Tafsir } \\
\text { Jalalain, Fathul Qorib, Mabadi'ul } \\
\text { awaliyah, Faroidu Saniyyah, } \\
\text { Mandumatul Baiquni }\end{array}$ \\
\hline $\begin{array}{l}\text { MA Al } \\
\text { Wathoniyyah, } \\
\text { Semarang }\end{array}$ & $\begin{array}{l}\text { Aqidah, Ushul fiqh, Figh, tafsir, } \\
\text { Hadith, Nahwu, Shorof, Mantiq, } \\
\text { Balaghoh, Mawaris }\end{array}$ \\
\hline
\end{tabular}

This practice started with the use of salafiyah books with madzahibil arba'ah madhhab at the level of Islamic law (sharia). That is, in the case of procedures for carrying out the worship practice it does not constitute only one opinion that is considered correct and allow other opinions to be equally right. This difference exists because it considers space and time as well as new variables that follow the current dynamics of the times and its needs. For example, the qoul jadid and qadim is a form of moderation for such changes based on the existence of illat.
The books are studied in learning activities at the curricular level, meanwhile in the extra-curricular level the boarding schools are conducting the Bahtsu masa'il once a year. Bahtsu Masa'il as a characteristic of boarding schools basically discusses about waqi'iyah problems that exist in society to find answers or solutions and could open the gates of moderation in the minds of the students. In line with this, Hani and Ashif in their research also stated that presenting the concept of problem-based fiqh learning could open a broad insight about the differences in Islamic law applied in society, therefore, they are able to position themselves to be in the middle and be moderate in responding to existing differences [15].

Bahtsu Masa'il when viewed from its activities reflects a moderate religious literacy learning model. This corresponds to the Head of Religious Education Teachers of Religious Education [16], which has seven stages. Namely reflection, inquiry, empathy, reasoning, and communication, writing or informing the answers to the problems using diction or terms that are easy to understand.

This bahtsu masail activity provides lessons for students to read religious texts and phenomena with a comprehensive perspective. At least they are able to understand literacy that might be seen, appreciated, and accessed outside their perspective. This allows students to be able to understand, appreciate, and respect plurality. Therefore, moderate Islamic religious understanding will become part of the way of thinking, behaving, and acting in the lives of the students.

Third, religious moderation in the MP in North Coast Region is also carried out through the education of national values which is reflected in the activities shown in Table 2.

Table 2. The activities of the Schools

\begin{tabular}{|l|l|}
\hline Schools & Activities \\
\hline $\begin{array}{l}\text { MA Al Anwar, } \\
\text { Sarang }\end{array}$ & $\begin{array}{l}\text { Flag Ceremony, Scouts, Paskibraka } \\
\text { (Flag Hoisting Troop), Singing the } \\
\text { verse Ya Lal Wathan }\end{array}$ \\
\hline $\begin{array}{l}\text { MA Al Hidayat, } \\
\text { Lasem }\end{array}$ & $\begin{array}{l}\text { Flag Ceremony, Scouts, Marching } \\
\text { Band, Paskibraka (Flag Hoisting } \\
\text { Troop) }\end{array}$ \\
\hline $\begin{array}{l}\text { MA Qudsiyyah, } \\
\text { Kudus }\end{array}$ & $\begin{array}{l}\text { Flag Ceremony, Scouts, Singing the } \\
\text { Nationality Shalawat (Asnawiyyah) }\end{array}$ \\
\hline $\begin{array}{l}\text { MA Al } \\
\text { Hidayah, Kudus }\end{array}$ & $\begin{array}{l}\text { Flag Ceremony, Scouts, Martial } \\
\text { Arts }\end{array}$ \\
\hline $\begin{array}{l}\text { MA Al } \\
\text { Wathoniyyah, } \\
\text { Semarang }\end{array}$ & $\begin{array}{l}\text { Frts, Ceremony, Scouts, Martial } \\
\text { Wathan }\end{array}$ \\
\hline
\end{tabular}


Some of these activities were carried out to instill the spirit of nationalism, some schools even we studied sang national poetry as a means of strengthening the spirit of nationalism. Like MA Al-Wathoniyyah and MA Al-Anwar Sarang that always chants the verse (poem) ya lal wathon written by KH Wahab Hasbullah every day. The idea of nationalism was also evident in the Shalawat Asnawiyah which was very popular among Javanese santri (Islamic students). This poem was created by KHR Asnawi who is also the founder of Madrasah Qudsiyyah, this verse is always chanted every day before teaching and learning activities begin. The poetry contained the spirit of nationalism values, as the lyrics that says aman aman aman aman Indonesia Raya aman, is a prayer for the safety and the glory of the nation of Indonesia.

Love for Pancasila, recognition of the ethos of citizenship, democratic values and diversity, MP has an additional value in this national education, namely enrichment of insights based on Islamic treasures. In contrast to general education, MP does not only teach nationalism, but also Islamic perspective nationalism. Because Islam has become the perspective, the delivery of national values automatically often uses Islamic insights. At this point, national and Islamic insights have become an integral paradigm in the MP Education process, the result of the integration of MP itself.

The seeds of nationalism are further able to dispel the radical behavior that will hinder the moderate attitudes in the students. The void of material that teaches national insight and the potential to be infused with radicalism in the Salafi Islamic boarding school has the probability to lead the students to turn into extremism and become anti-NKRI. Such conditions can be the forerunner to the birth of acute radicalism that leads to terrorism [17].

\section{CONCLUSION}

Islamic education in Madrasah-Pesantren (MP) has become the vanguard of religious moderation in Indonesia. This is inseparable from the quality of the Islamic culture which from the beginning became the social capital for this educational institution. The Islamic culture inherited from Wali who have formed a moderate Islamic style since the $13^{\text {th }}$ century AD. Sunan Kudus in his preaching has provided a way of life for future generations to behave moderately as exemplified by him who always respects others despite their differences. The moderate Islamic style of Sunan Kudus appears in Islamic Schools in the Pantura area which is broadly illustrated in the activities of the Islamic schools that prioritize tolerant attitudes, build a thinking tradition based on Islamic scientific treasures and strengthen the national education of Islamic perspective to avoid radical behavior. That way the students will have a moderate attitude as a provision for themselves in living their life as inherited from their ancestors.

\section{REFERENCES}

[1] Badan Litbang dan Diklat Kementerian Agama RI, Tanya Jawab Moderasi Beragama, Jakarta: Balitbang dan Diklat Kementerian Agama RI, 2019.

[2] C. L. Salcedo, Moderate Muslims: Myth or Reality? USAWC Strategy Research Project, Pennsylvania: US Army War College, 2007.

[3] A. P. Schmid, Moderate Muslims and Islamist Terrorism: Between Denial and Resistance, ICCT Research Paper, August, 2017.

[4] N. Faiqah, T. Pransiska, "Radikalisme Islam Vs. Moderasi Islam: Upaya Membangun Wajah Islam Indonesia yang Damai, Al-Fikra", Jurnal Ilmiah Keislaman, 17(1) $2018 \quad 33-60 . \quad$ DOI: http://dx.doi.org/10.24014/af.v17i1.5212

[5] Misrawi, Zuhairi. Hadratus Syaikh Hasyim Asy’ari Moderasi, Keutamaan, Dan Kebangsaan. Jakarta: PT Kompas Media Nusantara, 2016

[6] A. M. M. Al-Salabi, Al Wasathiyyah Fi Al-Qur'an Al-Karim Cairo: Maktabah at-Tabi'în, 2001

[7] M. H. Kamali, The Middle Path of Moderation in Islam: The Qur'ānic Principle of Wasathiyyah. New York: Oxford University Press, 2015

[8] Y. Qardhawi, Al-Kalimat Fi Al-Wasathiyah AlIslamiyah Wa Ma'alimaha, Cairo:Dar al-Shuruq. 2011

[9] M. Hilmy, "Whither Indonesia's Islamic Moderatism? A Reexamination on the Moderate Vision of Muhammadiyah and NU," Journal of Indonesian Islam, 07(01) 2013 24-48. DOI: 10.15642/JIIS.2013.7.1.24-48

[10] M. Fahri and A. Zaenuri, "Moderasi Beragama di Indonesia," Intizar, 25(2) 2019 95-100. DOI https://doi.org/10.19109/intizar.v25i2.5640 
[11] N. Said, Jejak Perjuangan Sunan Kudus dalam Membangun Karakter Bangsa, Bandung: Brillian Media Utama, 2010

[12] Graaf and Th.G.Th. Pigeaud, Kerajaan-kerajaan Islam pertama di Jawa : kajian sejarah politik abad ke-15 dan ke-16/, terjemahan bahasa Indonesia, Jakarta : Grafiti Press, 1985

[13] R. Wiranto dan Sawariyanto, Mengubah Tajug Menjadi Al-Quds, Yogyakarta: Gatra, 2001

[14] A. Faridah, "Membangun Karakter Melalui The Hidden Curriculum", Al Mabsut Jurnal Studi Islam dan Sosial, 9(2) 2015 107-115.
[15] H. Hikmatunnisa and A. AzZafi, "Penerapan NilaiNilai Moderasi Islam Dalam Pembelajaran Fiqih di PTKIN Menggunakan Konsep Problem-Based Learning", JIPIS, 29(1) 2020 27-35, DOI: https://doi.org/10.33592/jipis.v29i1.546

[16] DfES, "Literacy in Religious Education: Key Stage 3 National Strategy, 2004

[17] Najmudin and S. Said, "Penanaman Nilai Moderasi Islam Dan Wawasan Kebangsaan Pada Santri Pondok Pesantren Salafi Jami'atul Ikhwan Kabupaten Serang Banten," Jurnal Pendidikan Karakter JAWARA, 6(1) 2020. 